\title{
ДОСЛІДЖЕННЯ ЕГОЦЕНТРИЧНОГО МОВЛЕННЯ ДІТЕЙ СТАРШОГО ДОШКІЛЬНОГО ВІКУ
}

\section{Research of Egocentric Speech of Children of Senior Preschool Age}

\author{
Svitlana Demianenko \\ Ph.D. in Pedagogy, Associate Professor \\ Pereiaslav-Khmelnytskyi Hryhorii Skovoroda State Pedagogical University (Ukraine) \\ demianenko.lana@gmail.com \\ https://orcid.org/0000-0002-0161-7024
}

\begin{abstract}
Absrtact
In this work, one of the types of speech of older preschool children - egocentric - is analyzed. Scientific approaches to the vision of the problem of egocentric speech are clarified. The egocentric speech of older preschoolers was studied, the content of which is connected only with the utterances of children of metalanguage. The obtained empirical data once again convincingly proved the spontaneity of children's metalanguage and confirmed the need to develop different types of utterances of older preschoolers, to achieve success in communication and adequate utterances, including about units of speech.
\end{abstract}

Key words: coherent speech, egocentric speech, metalanguage, spontaneous expression.

\section{Ветуп \\ Introduction}

Мовленнєвий розвиток дитини є одним із важливих надбань дошкільного дитинства. Якісні зміни, що відбуваються у психіці дошкільників сприяють зростаючому темпу їхнього мовлення. У дитини з'являється потреба в побудові висловлювань, які виникають під час оволодіння навичками мовлення. Дошкільники часто говорять вголос ні до кого не звертаючись, при цьому мовлення дитини супроводжує та пов'язане з діяльністю, основним видом якої є гра. Таке монологічне мовлення дітей називається егоцентричним (Пиаже, 2001).

Під поняттям егоцентричне мовлення дітей розуміємо мовлення, яке насамперед відрізняється своїми функціями. «...Мовлення егоцентричне, - в першу чергу тому, що дитина говорить тільки про себе, так ніби вона голосно розмірковує». 
До егоцентричного мовлення відносяться повторення слів та складів, коментування, що використовує дитина для своїх дій, і «колективні монологи», які за умови присутності партнера не вимагають його розуміння (Пиаже, 2001).

Егоцентризм репрезентується мовленням, що супроводжує розв’язання завдань. За умови підвищення складності завдання, у дитини збільшується потенціал до оволодіння цим мовленням. Розвиток дитячого мислення здійснюється не від індивідуального до соціалізованого, а від соціального до індивідуального. Тому в егоцентричному мовленні вбачається перехідна стадія в розвитку мовлення від зовнішнього до внутрішнього (соціальне мовлення; егоцентричне мовлення; внутрішнє мовлення) (Выготский, 1982).

Mema cmammi - описати результати аналізу егоцентричного мовлення (висловлювань метамови) дітей старшого дошкільного віку та розкриття його особливостей.

\section{Методи та методики дослідження Methods and Techniques of the Research}

Для вивчення егоцентричного мовлення дітей старшого дошкільного віку використовували такі емпіричні методи: аудіо та відео записи дитячих висловлювань за типом егоцентричного мовлення, дискурс-аналіз, структурно-логічний аналіз, лінгвостатистичний метод.

\section{Результати \\ Results}

Дослідження дитячого мовлення показали, що потреба дитини у побудові зв'язних висловлювань виникає ще у ранньому віці. Для мовлення дітей 4-5 років характерна ситуативність, яка знижується у старшому дошкільному віці у зв'язку 3 навчанням різним типам монологічного висловлювання. Починаючи 3 5-6 років інтенсивно розвивається монологічне мовлення $\mathrm{y}$ наслідок завершення фонематичного розвитку i засвоєння морфологічної, граматичної і синтаксичної сторін рідної мови. Вивчаючи висловлювання дошкільників, які породжуються егоцентричним мовленням, виявили, що вони корінним чином відрізняються від типів монологів, яких навчають дітей у закладі дошкільної освіти.

Висловлювання дитини, яке виникає в егоцентричному мовленні, функціонально, структурно і ситуативно відрізняється від типу монологу, яким дитина оволодіває під навчальним впливом. На нашу думку, жоден із них не витісняє 
інший, хоча є окремими за своєю сутністю. В мовлення дітей старшого дошкільного віку вони існують паралельно. За дослідженнями С. Рубінштейна (Рубинштейн, 2000) егоцентричне мовлення зустрічається навіть у мовленні дорослих людей в моменти емоційної напруги.

Особливу цікавість представляло вивчення егоцентричного мовлення старших дошкільників, зміст якого був пов'язаний із висловлюваннями дітьми метамови. Егоцентричних висловлювань дітей старшого дошкільного віку іншого змісту ми не вивчали. Слухачем в егоцентричному мовленні є уявний чи реальний співбесідник. У цій ситуації дитині важливо не тільки здійснити мовленнєву дію, а також отримати зворотній результат - бути почутим. Дитині стає не потрібною не ілюзія розуміння матерії мови, не саме розуміння ровесника, на якого спрямоване його мовлення. В цій ситуації можемо розмежувати мовлення для себе (егоцентричне мовлення) i мовлення, яке несе певну інформацію. Некомунікативність, неспрямованість характерні ознаки егоцентричного мовлення $\epsilon$ протилежними мовленню безпосередньо спрямованого на реального співбесідника для впливу на нього.

3 аудіо запису мовлення дитини старшого дошкільного віку під час гри 3 лялькою було проаналізовано прояв ніким немотивованого мовлення. Дитина, граючись із ляльками «спілкується» з ними, тобто веде діалог, розповідає їм казку про азбуку, або влаштовує «навчання звукам, буквам, словам». Висловлювання дитини емоційні, мелодійні, розгорнуті, містять прояви метамови і хибні висловлювання про мовні явища. Наприклад, говорить - «Це буква [A], така [aаaаa]». Звертається до висаджених ляльок - «Скажіть звук!». Говорить: «Звук такий [а] називається».

Аналізуючи мовлення іншої дитини під час гри з машинками, зафіксоване егоцентричне мовлення має специфічну синтаксичну будову, характеризується уривчастістю, фрагментарністю, безв'язністю. Наприклад, хлопчик везе машинку, говорить - «дрррррр» ...задумується, ніби прислуховується до себе, обмірковує та каже: «букви ричать», далі ...викрикує - «ррричать!». Як бачимо, в егоцентричному висловлюванні дитина спонтанно намагається називати почуті звуки у наслідуванні звуку мотора. На наш погляд, тут, не знаючи чітко параметрів звука і букви як одиниць рідної мови дитина намагається вслухатись у промовляння ще раз і повторює голосніше натискаючи голосом на звуки, які викликали до себе увагу.

Варто зауважити що наведені приклади егоцентричних висловлювань дітей можна назвати мотивованими, тобто вони вираженні 3 певною метою.

Інші записані висловлювання повністю відрізнялися від попередніх. Аналізуючи егоцентричне висловлювання хлопчика 6-ти років було помічено збіднений синтаксис, переважання звуконаслідувань, проспівування відрізків мелодії, промовляння окремих звуків. Було чути окремі фрази, слова. В момент вимовляння 
фраз спостерігали чергування шепотіння 3 голосним мовлення $\mathrm{i}$ навіть викрикуванням. У момент, коли дитина повністю занурювалася в гру було чути говоріння на повний голос, текст був найбільш зв'язним. Наприклад, дитина грається та будує з кубиків із зображенням азбуки. ...Каже - «Так!» ... мелодійно виводить «y$y$-y-y», далі дії супроводжує мовленням - «...О! щзе ось [У] (бере кубик із літерою -у-) - поставлю». Продовжує будувати фортецю. Ставить зверху великий кубик із зображенням -О-. «Hi, [A] - го-ло-вна»...ледь чутно. Знімає і ставить кубик -А-. Наказує: -A-, «Ти - головна!». Будує і декламує голосно, виразно вірш: «Автобус їде по алеї, акація цьвіте в саду. А ми зібралися під нею, абетку вивчемо легку». Викрикує, схоплюється і біжить, повторяючи ще раз рядки куплету вірша. У цьому прикладі у егоцентричному мовленні дитина демонструє спонтанні висловлювання про звуки та буква мови.

\section{Висновки \\ Conclusions}

Отже, егоцентричне мовлення до кінця дошкільного віку починає затухати i поступово втрачати свої характерні ознаки у зв'зку зі зростаючою роллю розвитку мовленнєвої діяльності дітей старшого дошкільного віку. Егоцентричне мовлення поступається іншим типам висловлювань, які служать для цілеспрямованої передачі інформації. Аналіз отриманих результатів дає підстави стверджувати, що метамова народжується у дитячих егоцентричних висловлюваннях максимально спонтанно, так само як і саме егоцентричне мовлення. Разом із віковим дозріванням інтелекту, егоцентричне мовлення зменшується і зникає майже зовсім приблизно в 7-8 років. У період підготовки до школи і навчання грамоти перед дитиною постає інше завдання висловлюватися, в тому числі і про одиниці мовлення, адекватно і бути зрозумілим для інших, донести інформацію слухачу та не опинитися в ситуації комунікативного неуспіху.

\section{Література \\ References}

Выготский, Л.С. (1982). Мышление и речь. Проблемы общей психологи. Собрание сочинений (Т. 1-6). Москва: Педагогика.

Пиаже, Ж. (1994). Речь и мышиление ребенка. Москва: Педагогика-Пресс.

Рубинштейн, С.Л. (2000). Основы общей психологи. Санкт-Петербург: Издательство «Питер». 